\title{
SOUTH SLAVIC-UKRAINIAN PHONETIC AND GRAPHIC VARIABILITY IN RELIGIOUS MONUMENTS OF THE $14^{\mathrm{TH}}-15^{\mathrm{TH}}$ CENTURIES
}

\author{
Inna Tsaralunga \\ Khmelnytsky National University (Ukraine)
}

\begin{abstract}
As a result of the analysis of liturgical texts of the $14^{\text {th }}-15^{\text {th }}$ centuries created in the territory of Ukraine, expressive signs of interaction between the Old Bulgarian graphic and spelling system and the Ukrainian folk speech are recorded. Manifestations of the phonetic and graphic South Slavic-Ukrainian variability are associated with the following linguistic phenomena in the vocalism and consonantism of religious monuments: continuity of the former*e, ${ }^{*} a$ and ${ }^{*} Q$; change of the initial $*$ je into $o$; transition of $e$ into $o$ after hushings and $u$; reduction of $u>b$ before iotated vowels; confusion of unstressed $u$ and $e$; development of sound combinations *tort, *tolt, *tert, *telt; reflexes of sound combinations $в p, \boldsymbol{b} л$, ьp $, \quad, \pi$; hardening of $p^{\prime}$; hardness/softness of hushing consonants; dissimilation and simplification of consonants; change of sound combinations $* d j,{ }^{*} z d j$ and ${ }^{*} t j,{ }^{*} k t$.

In the phonetic system of the studied monuments, the interaction of the traditional writing of that time and the local vernacular is observed, in particular, the phonetic features of the North Ukrainian and the South-West Ukrainian dialects are revealed. The study of the language of religious monuments taking into account the results of other research in the field of philology, paleography, theology has undeniable prospects for linguistic interpretation of church books with the definition of local language traditions of the time, their localization as elements of the Slavic written culture, resolving debatable issues regarding the formation, chronology and systematization of the church-written corpus.
\end{abstract}

Keywords: religious monument; variability; phonetic system; the Old Bulgarian language, the Ukrainian dialect influence

\section{Topicality}

The period of the $14^{\text {th }}-15^{\text {th }}$ centuries was marked by the active spread of liturgical literature in the territory of Ukraine. The idea of the Church Slavonic basis of religious texts of that time is traditional in the Slavic studies. According to the theory of diglossia common in the Ukrainian scientific studies, two literary and written languages functioned in parallel in Kyivan Rus: The Old Slavonic, which acquired 
the local Ukrainian phonetic, grammatical, and lexical features under the influence of living language, and the Old Ukrainian, which was based on the vernacular (Uspenskij, 1994, p. 4 - 8; Skab, 2014, p. 45 - 46). The statement about the Old Bulgarian origin of the religious monuments distributed on the territory of Ukraine of this time was quite reasonably expressed by A. Stamenova: "In other Slavic and non-Slavic countries, lists of liturgical and related texts, translated or created in the Old Bulgarian language, are distributed. This is how its editions (derivations, local types) are formed, for example, Moravian, Croatian, Serbian,... Ukrainian, Belarusian, Vlach-Moldavian. They are connected by the common Old Bulgarian language basis, but differ in secondary ethnic local layers as a result of functioning in a foreign language environment" (Stamenova, 2017: 29).

\section{Research sources}

There are few religious monuments of the $14^{\text {th }}$ century, marked by the consequences of the military attacks of Batu Khan, the widespread destruction of cultural artifacts in the Ukrainian and adjacent territories. As L. Zhukovska emphasized: "The vast majority of them are written in the Galician-Volyn, Novgorod, Pskov, Rostov-Suzdal, Smolensk-Polotsk language regions... The relatively small number of ancient lists of the Gospels from the southern and eastern regions of Russia, including from Kyiv land is due to the fact that a large number of manuscripts in these areas were lost during the Mongol-Tatar invasion" (Zhukovskaya, 1976). These are primarily such liturgical manuscripts of the $14^{\text {th }}$ century: The Putna Gospel of the $13^{\text {th }}-14^{\text {th }}$ centuries, the Gospel of Verkovich of the $13^{\text {th }}-14^{\text {th }}$ centuries, the Bybelskyi Apostle of the $14^{\text {th }}$ century, the Lutsk Gospel of the $14^{\text {th }}$ century, the Lavryshiv Gospel of the $14^{\text {th }}$ century, the Pandects of Antioch of 1307, the Lutsk Psalter of 1384, the Kyiv Psalter of 1397, the Polycarp's Gospel of 1307, the Panteleimon's Gospel of 1317.

Due to the economic and socio-political development of the Ukrainian lands, the $15^{\text {th }}$ century was characterized by the active formation of centers of book writing. The transition from parchment to a more convenient and cheaper material - paper - contributed to the increase of written literature, its wider penetration into the popular environment. Rich linguistic material is presented in the following written records: Ismaragd of the $15^{\text {th }}$ century, the Kamyanka-Strumyliv Gospel of 1411, the Chetia-Mineya of 1489, the Teachings of Ephraim the Syryn of 1492, the Apostle of the $15^{\text {th }}$ century from the village of Antonivtsi in Kremenets region, the Korolevo Gospel of 1401, the Uzhhorod Half-Uncial of the beginning of the $15^{\text {th }}$ century, the Mukachevo Psalter of the $15^{\text {th }}$ century.

\section{Analysis of research on a scientific problem}

These liturgical monuments are an invaluable source for studying the history of language, as the language system is realized in a set of linguistic facts recorded at the same time, in the same place. As a result, they have become the subject of research by many linguists, both in the context of general linguistic reviews - V. An- 
ichenko (Anichjenka, 1966), L. Bulakhovskyi (Bulakhovskyi, 1977), L. Zhukovska (Zhukovskaya, 1959), A. Stamenova (Stamenova, 2017), J. Stradomski (Stradomski, 2014), S. Temchin (Temchin, 2009) and others; and works on individual linguistic monuments - K. Verdiani (Verdiani, 1954), P. Kopko (Kopko, 1912), V. Nimchuk (Nimchuk, 1997), C. McRobert (McRobert, 2010), P. Popesku (Popesku, 1962), M. Smorąg-Różycka (Smorąg-Różycka, 1999), V. Jagic (Jagic, 1894) and others. However, special attention should be paid to the issue of the South SlavicUkrainian phonetic and graphic variability in these books, which is a significant gap in historical and linguistic studies.

The purpose of our scientific work - based on a thorough analysis of preserved and accessible texts of religious monuments of the $14^{\text {th }}-15^{\text {th }}$ centuries from the territory of Ukraine to identify examples of the phonetic and graphic South SlavicUkrainian variability, to clarify linguistic phenomena attested in parallel linguistic elements, to analyze linguistic interactions as possible causes of variability.

\section{Presentation of the main material and justification of the research results}

Analysis of the problem of the relationship between spelling and pronunciation in religious manuscripts of the $14^{\text {th }}-15^{\text {th }}$ centuries showed that the history of the transmission of vowels and consonants is complex and contradictory, which is due to the variability of graphemes, phonetic oscillations due to the influence of local speech.

\section{Vocalism}

Variable spellings due to irregular use of $A$ i $\not$, transition of the ancient $* e$ and $* Q$ in pure vowels. In the liturgical texts of the $14^{\text {th }}$ century we find a consistent interchange of the letters $A-X, X-I X$ in the Gospel of Verkovich, typical of the Old Bulgarian monuments: Алч Аџи СВ, 160 a, вьсплач Ат (b)сн СВ, 87 а, имлшаго $\mathrm{CB}, 41$ а, вь слботоу $\mathrm{CB}, 46$ а - вьзжшк

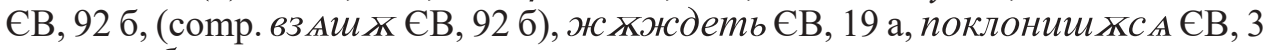

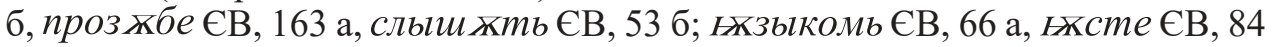
б, силы нбснын н 66 а - вьпинашаго ЄВ, 176 б, оупованать ЄВ, 168 a etc. The confusion of the yus is represented in the Mukachevo Psalter: па хчина МП, 38 -

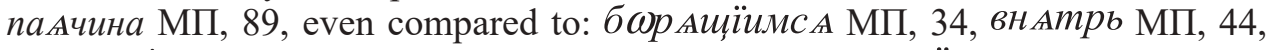
капл Ащіа МП, 71, празноудщзаго МП, 41, призыванщїихъ МП, 98, на прА моА МП, 34, оузрА МП, 5, въ главж Аглоу МП, 117 and others. This phenomenon is even more widely represented in the Kamyanka-Strumyliv Gospel: вол $\boldsymbol{A}$ (Possessive case, singular) КСЄ, 33, 181, вън Атръ КСЄ, 52 зв., гласъАт КСЄ, 12, на земл А (Possessive case, singular) KCС, 132 зв., им Аm КСС, 24 зв., Им Аџи

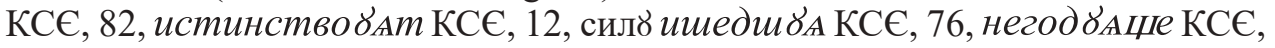
93, за некодА крамоло бывшо дА КСЄ, 154, в геенб огньн дА КСС, 43, 85, не требодАть КСЄ, 36 зв. and many others.

Reflection of the former ${ }^{*} e$ and ${ }^{*} a$. The language of the church at that time reflected the North Ukrainian dialects, in particular in the varied spell- 
ings caused by the reflection of the former ${ }^{*} e$ and ${ }^{*} a$. For example, in the texts of the Kyiv Psalter: оуглебохъ КП, 90 зв. - оугл Абноу КП, 91 зв.; ефишплене КП, 97, заєиємь КП, 144, кленахоуса КП, 139 зв., прозебаи КП, 143 зв., прозебаюшаға КП, 224 зв., прокленоуть КП, 158 зв. and the like, but: nам Ать КП, 10 зв., с бил КП, 122, тыссашь КП, 117, клАхсл КП, 122 etc. According to the conclusions of V. Nimchuk, "...the strengthening of the northern element in Kyiv region began in the twelfth century and apparently increased after the TatarMongol invasion", therefore, the native language of the scribe was Ukrainian in its northern form. (Nimchuk, 1997, p. 21). Many examples of the change of *e and *'a into $e$ in the unstressed position can be found in the Gospel of Verkovich, first of all in the verb affix -сA: не боит все $\mathrm{CB}, 146$ б, вьзрадоугетсе 16 б, кланнашесе $\mathrm{EB}, 23$ б, наоучитесе $\mathrm{GB}, 26$ a, Фставл ветсе $\mathrm{CB}, 40$ a, прославитсе $\mathrm{CB}, 16$ a, родисе $\mathrm{GB}, 16$ б, чюдисе $\mathrm{CB}, 47$ б and others; in the endings of nouns: вь име мою $\mathrm{EB}, 21 \mathrm{a}$; in the middle of the words: $\omega$ кнезы $\mathrm{CB}, 29$ б, двою на десете $\mathrm{CB}, 50$ б, гезыкь $\mathrm{CB}, 47$ a; as well as in the stressed position: иночедь $\mathrm{CB}, 45$ б, начело $\mathrm{CB}$, 38 б, проклети $\mathrm{CB}, 19$ б, свезано $\mathrm{EB}, 20$ б, чедо $\mathrm{EB}, 48$ a etc.

The spellings in the Lutsk Psalter and the Lutsk Gospel related to the transmission of the former ${ }^{*} e$ and ${ }^{*} a$ may testify to more noticeable spelling tendencies, the skill of the scribes of that time: $и м \mathrm{~A}$ ЛП, 8 зв., кнАзи, ғазыци ЛП, 2, любацимъ его ЛП, 30 зв., памАть ЛП, 10 зв., пр бпогасаға ЛП, 22, смАтес А ЛП, 5 зв., с ъмА ЛП, 28 and others; грғадоуша, гдиного на дес

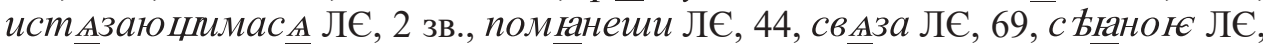
61 etc. Therefore, we did not find in these manuscripts any use of e in the place *e and *'a in the unstressed position, attested in other monuments of Polissya. This may be due to the fact that the scribe consistently used the graphemes $A$ ( $F$ a) to convey the vowel e under the strong influence of spelling traditions.

In Hagiography of 1489, the grapheme $e$ was recorded in accordance with the Proto-Slavic $e$ in an unstressed position: хто жедаєть - жаж( $)$ жииих, and: колодезь, паметайте, жены плесание Четья, 39. The grapheme $e$ instead of $я$ is used in the Apostle of Kremenets region: клАтвою - клен ътесл, неуведаемьий, светилища, Ф страстех Ап, 70, 72; in Ismaragd: продлъжєю(т) Ізм. №488, 7, разврашє ґеть Ізм. №489, 60, but: Кн Агин А Ізм. №489, 33 зв., $м$ Алт жшеес А Ізм. №488, 90, тыс АШШ Ізм. №488, 44. Isolated cases of substituting $A(r)$ through $e$ occur in the texts created in the south-western territories of Ukraine: in the Mukachevo Psalter: блхде $(m)$ (3rd person plural) ср(д)цемь МП, 94, крштцїи же насл бде( $m$ (3rd person plural) земла МП, 36, тежи $b(x)$ МП, 34, we also compare the inverse confusion: чАлюсти МП, 31; in the Kamyanka-Strumyliv Gospel: стезатиса ст Азатис А КСС, 43 зв., тежсателем КСЄ, 124, болеша АСС, 37 зв., свезавше КСЕ, 50 зв., плашеницю КСС, 95 зв.

The oscillations caused by the transition of the initial $j e$ into $o$. Some signs of change of the initial je into $o$ are found in numerals 
and derived words: єєдинъ ЛЄ, 2 зв., єдины ПЄ, 3, единого КП, 5 зв. - одинъ ЛС, 2 зв., however, the Church Slavonic forms predominate: единъ ЛП, 8 зв., гединого БА, 3 зв., единомылилениемь КП, 74, единою КП, 82, единачадаго ПЄ, 2, гединочадыли ЛЄ, 1 зв., гєдиночадъ ЛП, 32, гедін ъмь Лавр Є, 54 зв. еtс. We also observe the oscillation in other parts of speech: елеемь КП, 62 - ол вемь ЛП, 28 зв., 192 - Юсифови ПС, 16, КСсифь-Осифъ Лавр Є, 14-14 зв., but: езера КП, 162, гєзеро Лавр Є, 46, при езер в ПЄ, 89, елень КП, 57, сйве ефремови КП, 106 and the like. Most traditional spellings are due to the specifics of the religious style, but in the monuments of official and business writing of that time, the cases of spelling $o$, which has become established in the modern East Slavic literary languages, significantly prevail (Tsaralunga, 2017, p. 67-68).

The oscillations caused by the transition of $e$ into $o$ after the hushing sound and $u$. Cases of traditional spelling are combined with the specific Ukrainian phonetic feature - the transition of $e>o$ in variable spellings: бчола - бчель, вже - вжо, єщо - єще, жолчь -желчи, жона -жену, предотече - пр (д)тчо Четья, 37-38; we also compare: говоречо, жовтый, радоуючос старио(м), черницою, чого, чоловъкъ and the like Четья, 37-38.

There are vowel oscillations in the adjective forms of the Uzhhorod HalfUncial: давшомоу, изведшомоу, оубившомоу, оутвердшомоу УП, 93 а-93 б отр Асшемоу, створшемоу, поразившемоу УП, 93 a-93 б and the like; in the Mukachevo Psalter: благод Бавшому МП, 12, 56, весел Ащомоу МП, 42, въшедшому, нищому МП, 67, град жщому МП, 70, жив хщомоу МП, 122, щомб МП, 75 -живуще(м) МП, 30 etc; in the texts of the Kamyanka-Strumyliv Gospel: чотыромь КСЄ, 8 зв. - четыри КСЄ, 10 зв., чотыродес Атницю КСЄ, 1 зв., чотыроличныи КСЄ, 66 зв., as well as: кағєщомс А КС€, 137, чоловьк КСС, 138 зв. The Apostle from Kremenets region: ничого, чому, but: лищемирїе Ап, 70, 73; Ismaragd: въставшои Ізм. №489, 172 зв., пр бход Ашо Ізм. №488, 15 зв., ничого Ізм. №488, 5, 11 зв., 17 зв., чого Ізм. №488, 14 зв. еtс.

Reduction of $u>b$ before iotated vowels. Yu. Shevelyov drew attention to the optionality of writing $u$ and $b$ before $j$ in church monuments (Shevelov, 2002, p. 352). Many similar parallel ancient East Slavic inscriptions with $b$ before iotated ones, which reflect living speech, in accordance with the Old Slavic $u$, inscriptions, are found in the Lutsk Psalter: $\partial$ бғаньга ЛП, 19, любовью ЛП, 30, Фружье ЛП, 18, покағаньюмь ЛП, 20, пос бченьға ЛП, 18 зв., селенье ЛП, 23 зв., оугльге ЛП, 21 and others, comp.: безаконие ЛП, 15 зв., достоганиге ЛП, 16 зв., камениға ЛП, 24, промениюе ЛП, 19, радостию 25 зв., оуглике 20 зв., оумилениға ЛП, 20, оупованике 16 зв. etc. Word forms with $b$ instead of $u$ dominate in the Lutsk Gospel of the $14^{\text {th }}$ century: Бљ ЛЄ, 11, Марьга ЛЄ, 12 зв., оу преломленьи ЛЄ, 3 зв., радостью ЛЄ, 6 зв., подъ съмоковью ЛЄ, 4 зв., оупьютьсға ЛЄ, 8 зв. and many similar; in the endings of 
nouns in the Lavryshiv Gospel: писаньғе Лавр С, 49 зв., подножью Лавр $€, 80$ зв., рождьғ Лавр Є, 39 зв., свьт бньға Лавр Є, 12 зв., оуздыханьға Лавр $€, 14$ 3в. etc. It should be noted that the Kyiv Psalter also represents the spelling with $b$ in accordance with the ancient with $u$ before the iotated ones: бездмь ға КП, 51 зв.,

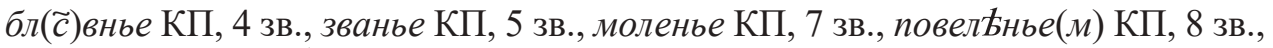
слинье КП, 44 зв., блговоленіга КП, 7 зв., веселиға КП, 17 зв. and others. In the Pandects of Antioch we do not observe variability, as vernacular forms prevail: въ безмолвьи ПА, 5 а, въздержанью ПА, 22 б, житью ПА, 18 б, с лестью ПА, 154 б, с напастью ПА, 74 б, бес пр бтыканьға ПА, 50 а, без роптаньға ПА, 82 а, ко см бр бнью ПА, 160 б and the like. Variable spellings related to the reduction of $u>b$ before iotated vowels are contained in the Uzhhorod Half-Uncial: братьra - братїа УП, 9 б, веселье УП, 194 а - веселие УП, 193 б, в къльи УП, 16 б - в кБлии УП, 10 а, пью УП, 192 а - пию УП, 187 б and many others. Similar changes are represented in the Teachings of Ephraim the Syryn: братьи ЄC, 77 зв. -братия ЄС, 298, во житьи ЄС, 32 зв. - у житии ЄС, 48, многословъсью ЄС, 22 зв. - многословьсию ЄС, 208 зв. and many similar.

Confusion of unstressed $u$ and $e$. Cases of oscillations of the unstressed $u$ and $e$ in liturgical texts of the $14^{\text {th }}$ century are rare: не прегрбиа $(\mathrm{m})-$ пригръиа (m) КП, 44 зв., призри ЛП, 27 зв. - презри ЛП, 9 зв., преидоша ЛП, 21 - придъте ЛП, 31, прелагаютса КП, 63, преидоша КП, 98 зв., преплывають КП, 144 зв., в зимли КП, 109, исправляюче Полікарп Є, 112, прибывает ПЄ, 21, прикратилис А - прбкрат Ать с А ПЄ, 143, са прикратили СВ, 86 б еtс. In general, the process of converging the unstressed $u$ and $e$ is very vaguely represented by the religious monuments of the $14^{\text {th }}$ century. Note: researchers believe that this feature, which belongs to the characteristic Ukrainian language features and is widely used today in many Ukrainian dialects, appeared in writing around the middle of the $15^{\text {th }}$ century (Bulakhovskyi, 1977, p. 250; Shevelov, 2002, p. $665-666$ ).

In the religious monuments of the $15^{\text {th }}$ century: придаd $A m$ - nредаd $A m$ KCE, 53 зв., пребываєшь-прибыває (m), претерпъль - притерпћль Четья, 47; in the Apostle of the $15^{\text {th }}$ century from Kremenets region: въ времА посльдние, не раздражайти, nомазавше Ап, 70, 73; in the Teachings of Ephraim the Syryn: негыблимаго ЄC, 16, не-

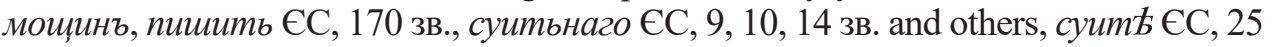
зв.; in the Uzhhorod Half-Uncial: прїчасникъ - прегръиїх УП, 2 б-2 а, прегрқшать УП, 67 б, пречюдныли УП, 131 б, кернӥии УП, 76 a and others. The spelling of $u$ instead of $e$ is typical of the Kamyanka-Strumyliv Gospel: пАть таланть еси придал КСЄ, 56, прикратилис А КСС, 54, припо Асавс А КСЄ, 188 зв., сториийю КСЄ, 119 зв., хировими КСС, 8 зв.; Ismaragd: Василеи Ізм. № 488, 15 зв., ДеФнисьға Ізм. № 489,3 , живуше (x) Ізм. № 489, 15 зв., жинитис А Ізм. № 488, 49, пом Анить Ізм. № 488, 37, сед Ать Ізм. № 488, 9, сотворете Ізм. № 488, 37, ходете Ізм. № 488, 55.

Variability associated with *tort, *tolt, *tert, *telt sound combinations reflexes. Significant influence of the South Slavic written 
traditions affected the spelling of continuations of *tort, *tolt, *tert, *telt sound combinations. Since the examples of the development of the pleophony in the stud-

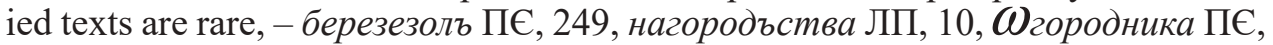
$246,-$ it is possible to state consistent observance of the traditions of book-writing operating at that time. This is consistently confirmed by examples of word forms in the Lutsk Gospel: брашно ЛЄ, 12, възвратистасл ЛЄ, 3 зв., гла(с) ЛЄ, 2, града ЛЄ, 4, зъдравъ ЛЄ, 16, въ средоу ЛЄ, 14, посрђдъ ЛЄ, 3 etc; in the Lutsk Psalter: враждоуюца ЛП, 3 зв., грады ЛП, 10 зв., дръво ЛП, 18 зв., младенечь ЛП, 7 зв., посръдъ чръва ЛП, 27, прахъ ЛП, 23, пръвыле ЛП, 7 зв., оуслади ЛП, 19 зв. and many others; in the Kyiv Psalter: власъ, главы, посрам Атсл КП, 55 зв., гла(с) КП, 5 зв., масло кравье КП, 209 зв., пльниль КП, 89, позлацена(x) КП, 62, посреде КП, 65 etc. In the Pandects of Antioch the nonpleophonic forms prevail: из града ПА, 165 б, дърага ПА, 291 а, многозраченъ ПА, 108 а, пръд лицемь ПА, 38 б, схранить ПА, 179 б, however, it is also witnessed: ворожъньа ПА, 193 б, въ деревъ ПА, 48 б, сволокъ сА ПА, 32 а.

The traditional spelling in the transmission of the former sound combinations *tort, *tert is reflected in the Lavryshiv Gospel: бранить Лавр С, 94 зв., жр ъбна Лавр Є, 117, мръжа Лавр Є, 59, посрђдъ Лавр Є, 45 зв., срђду Лавр Є, 165 зв., стрьгуще Лавр $\mathrm{C}, 153$ and many similar. The traditional spelling in the Putna Gospel is quite consistently followed: по брқгоу ПЄ, 64, врага ПЄ, 55, вратьл ПЄ, 217, нђ възбраните ПЄ, 230, срђдъ васъ ПЄ, 2, схранити ПЄ, 40, оузвратиста сл ПЄ, 4, въ чръвъ ПЄ, 229 and others; in the Bybelskyi Apostle: власы БА, 6 зв., глава БА, 6, младъ БА, 8 зв., млька БА, 17, сладиъ БА, 24, БА, 31, съграждағеть БА, 3 зв., чръсь БА, 5 etc; in the Gospel of Verkovich: силж вражи ж СВ, 166 б, жскым(и) враты СВ, 159 а, с. 6, посрдь СВ, 163 а, $n p \hbar(\partial) \omega($ т)цемь $\mathrm{CB}, 216$ and the like.

In the $15^{\text {th }}$ century, consistent traditional writings became the part of most religious monuments: град, Фбратит, пред бгом, сребро АП, 72-73; вразї УП, 10 б, власьға УП, 151 а, врата УП, 182 а, древа УП, 70 б, младенець УП, 95 б, предними дверми УП, 68 б, сладкына УП, 20 б, сраменъ УП, 120 а, чрево УП, 65 a, but: березо $(л)$ УП, 154 a; the Teachings of Ephraim the Syryn: злато СС, 103 зв., небрьжъньі ЄС, 4, пръдложенью СС, 241 зв., прбкословъсьници СС, 121, срамляимося ЄС, 75 зв.; the Mukachevo Psalter: враждоу жижа (!) МП, 2, гла(c) МП, 28, меташи жръбі А МП, 21, въ риза(х) позлащена $(x)$ МП, 44, посрамлатсл МП, 82, пр Аполовленіе МП, 101, из чръва МП, 70; the KamyankaStrumyliv Gospel: по брегоð КСС, 25, 75 зв., гласб Ат КСЄ, 12, златниию КСЄ, 50 зв., пред събою КСС, 20, страны тирскїа КСС, 38 зв., ис чрева КСС, 45; Ismaragd: вранове Ізм. № 488, 227 зв., гласове Ізм. № 488, 235, града Ізм. № 488, 55, два древа Ізм. № 488, 27 зв., наслаженїа Ізм. № 488, 24 зв., небреженіе Ізм. № 488, 39, Фбраоешт Ізм. № 488, 30 зв., чрес повелние Ізм. № 489, 15 зв. and others. 
However, the language of Ismaragd also reflects the pleophony forms: вередuши Ізм. № 488, 118, головою Ізм. № 488, 5 зв., голо(д) Ізм. № 488, 235, голодень, пере(ж) Ізм. № 488, 6 зв., золотомъ Ізм. № 489, 90, не Фтеребле(н), не соромоти Ізм. № 488, 4-4 зв., полонъ Ізм. № 488, 11, оухоронити Ізм. № 488, 9 etc. Obviously, the language of the church became more and more close to the vernacular, so the liturgical books include expressions of pleophony.

Variability of reflexes of combinations $b p, \quad b \pi, \quad b p, \quad b \pi$. Signs of change are witnessed in the monuments of religious style $b p>е p ; \quad b л>$ ол: дерзъноу Лавр Є, 134 зв., долженъ Лавр Є, 103, жертвоу ЛП, 24 зв., зерно Лавр Є, 11 зв., наверхъ ЛП, 7, наполн (ите) Лавр Є, 10, столпъ Лавр Є, 113 зв., торжникомъ Лавр $€, 3$, торжьникомъ Полікарп $€$, 32, оумолъкни Лавр $€$, 66, червь ЛП, 26 зв. and the like. In the Gospel of Verkovich there is a spelling $b, b$ after the smooth: дльжьнь $\mathrm{EB}, 34$ а, дрьжитсе $\mathrm{EB}, 24$ а, $\omega($ м)врьжетсе $\mathrm{EB}, 21$ б, тльиате $\mathrm{CB}, 54$ а, вь четврьт жнА $\mathrm{GB}, 30$ б etc, caused, apparently, by the Old Bulgarian influence and peculiarities of spelling of that time.

Newer constructions with vowels of full creation in the Uzhhorod Half-Uncial often correspond to the ancient combination of $b p, \quad b л, \quad s p$, $в л$ between consonants: волна, сполнис А УП, 11 а, держави УП, 18 б, державенъ, скорбъти УП, 120 а, дерзновенїе УП, 196 а, долготерпьнью УП, 196 б, испроверже УП, 30 а, кормАцихъ УП, 10 а, одержа УП, 27 а, женъ, оутвержение УП, 208 а, скорби УП, 5 а, скорблю УП, 78 а, скорбь УП, 9 а, холмъ УП, 91 б еtc. Older constructions with reduced vowels are less common: дрьжава УП, 121 а, дръжавоу УП, 17 а, їстръженьға УП, 121 б, одръжамес А, Фдръжа УП, 120 а, скрьбь УП, 208 and others.

The words reduced in the middle are very consistently used in the texts of the Mukachevo Psalter: влънь МП, 94, на връби МП, 190, връхь МП, 39, въспоплъзновеніа 55, грълица МП, 83, длъготръпъливь МП, 7, жрътвж, скръби, тАжккосръдіи МП, 4, мрътьвь МП, 30, одръжаніе, растръгнъ(м) МП, 2, плъкь МП, 26, пръвыл МП, 43, пръсть МП, 6, 8, съвръииль МП, 39, съмръть МП, 17, чръвь МП, 21, чрътога МП, 18 and others; the Kamyanka-Strumyliv Gospel: вльхвы КСЄ, 14 зв., длъгы КСЄ, 20 зв., KCE, 22 and the like.

\section{Consonantism}

Hardening of $\mathrm{p}^{\prime}$. Signs of depalatalization of $p^{\prime}$ before vowels $a$ and $y$ are represented by a small number of spellings, so, given the specifics of religious writing of that time, it is possible to state the predominance of traditional spelling in liturgical texts. There are some exceptions, apparently caused by vernacular influence: ґзєро гороушє Лавр Є, 111; кесаръ ЄВ, 87 б, 119 б, Лазару КП 67, Лазара СВ, 48 а, мора СВ, 30 б, назаранине СВ, 42 б, прамо Лавр С , 117; рибара $\mathrm{EB}, 23$ а, йроу $\mathrm{EB}, 33$ б and the like, but: боур А КП, 67 зв., вечерю БА, 6 
зв., вечер А СВ, 55 а, горю (дієсл.) ПЄ, 96, гр Адыи ЛП, 28 зв., др Ахла ЛЄ, 2 зв., зАр А (!) и слинце КП, 101 зв., мор А КП, 97, напр Аже ЛП, 7, напр Аже КП, 9, Флтарю КП, 59, польмор А ЛЄ, 11, рАдника БА, 10, рАсны КП, 62 зв., Сухарь ПЄ, 27, творю БА, 33 зВ., творю ПЄ, 26, твор Ацимъ КП, 40 зв., and, obviously, hyperic, тр Апезоу ЛП, 28 зв., тр Апеза КП, 92 зв.

Signs of the hardening of $p^{\prime}$, inherent in the Ukrainian dialects, are recorded in the Apostle of Kremenets region: сотворб, гра(д)ущих Ап, 70; the KamyankaStrumyliv Gospel: ко морю КСС, 72 - ко морб КСС, 70, сътворю КСЄ, 86 зв. - сътворд КСЄ, 191; in Ismaragd lists: бор ж(m) Ізм. № 488, 21, по мор ж Ізм. № 488, 41, Фбрашеши Ізм. № 488, 30 зв., сотворб Ізм. № 489, 56 etc.

Signs of hushing sounds' hardening/softening. Often linguistic parallelism in religious texts is associated with the processes of hardening of hushins: конч ветьсл $\mathrm{CB}, 99$ а - скончатисл $\mathrm{CB}, 11$ б, ФбрАШ - -брАшб КП, 89 зв., притьчА СВ, 61 а - прича СВ, 46 б, чюдеса КП, 152 зв. - чбдеса КП, 150 etc. But along with the traditional spellings: несоушю КП, 8, кожю КП, 143, нашю КП, 61, постыжюс А КП, 39 зв., вь притчю КП, 66, оутвержю КП, 41 зв., чюдно КП, 9, чюжемоу КП, 60 зв. and others, we record word forms that may indicate the depalatalization of consonants: величатис А КП, 13, люса, КП, 5, моужа КП, 6, одеръжацаға, приближатсл КП, 41, плача КП, 7 зв., вь притъчахъ КП, 105 3в. etc.

The softness of the hushings is reflected in most examples from the Lutsk Gospel: не вижю ЛЄ, 7 зв., дышюџю ЛЄ, 11 зв., межю собою ЛЄ, 14 зв., недоставию ЛС, 8, одежю ЛС, 13, помажють ЛЄ, 12 зв., оуложю ЛС, 7 зв. and others, but there are examples of the hardening of hushings: гргадоуша ЛС, 3 зв., отроча ЛЄ, 13 зв., плацаницю ЛЄ, 12 зв., пребываюшаго ЛЄ, 10 зв., оусльшать ЛЄ, 10 etc. We find parallelism in the graphic transmission of hushing consonants in the Lutsk Psalter: насыцюсл ЛП, 18 зв., Фмочю ЛП, 5 зв., оуврачюи ЛП, 19, поглажю ЛП, 23, не постыжюса ЛП, 32 зв., чюдно ЛП, 7, чюжии ЛП, 23, сь шюмомь ЛП, 10 зв. and the like, but there are cases of another implementation of hushing: вънчалъ ЛП, 7 зв., державно ЛП, 16 зв., издалеча ЛП, 24, наоучаға ЛП, 22, Фбницавша ЛП, 8-8 зв., подвижатьса ЛП, 17 зв., плача ЛП, 6-6 зв., шатамас А ЛП, 2 etc; in the texts of the Pandects of Antioch: бывъшюю ПА, 7 б, въздвижють ПА, 18 б, чююмъ ПА, 106 б, надежю ПА, 14, плачюше ПА, 223 а, св бцю ПА, 61 a, не хошю ПА, 214 а, чювествьюе ПА, 61 б and the like., but: дйа ПА, 3 б, изьв бщати ПА, 153 б, лъжа ПА, 106 б, о начатъиъ ПА, 9 б, осълоушаль ПА, 99 б, пиша ПА, 18 а, повъчатис А ПА, 43 б, ръжа ПА, 29 a, чають ПА, 41 a and others.

We record similar changes in the monuments of the south-west, namely - in the Bybelskyi Apostle: вашю БА, 33 зв., възложю БА, 3, наоучю БА, 10 зв., плачюшесА БА, 2 зв., положю БА, 4 зв., не пошажю БА, 26, прохожю БА, 12 зв., в чюж Бхъ БА, 23 and others, but: вама БА, 35 зв., причастнищи БА, 13 зв., 
троужаюшемоуса БА, 24 зв., чаша БА, 5 etc.; in the Putna Gospel: вложю ПЄ, 9, жњж жшта ПЄ, 212, сльию ПЄ, 13, притчю ПЄ, 33, стражю ПЄ, 107, оузврацюс А ПЄ, 103, чашю ПЄ, 66, чловъчю ПЄ, 152, but: възв ъшаи ПЄ, 104, жатва ПЄ, 30, лежаца ПЄ, 3, начаша ПЄ, 107, Фт Агъчають ПЄ, 121, въ прїтчахъ ПЄ, 94 and the like; in the Gospel of Verkovich: бышы СВ, 11 а, вьпросиил СВ, 7 б, плачАшас А $\mathrm{CB}, 80$ б, праведничА $\mathrm{CB}, 28$ а, притьчА СB, 61 a, but: им Ашаго $\mathrm{CB}, 41$ а, им Ашоу $\mathrm{CB}, 33$ б, $\omega($ m) в бшаш х $\mathrm{EB}, 2$ б8, печалнї $\mathrm{EB}, 16$ a etc.

Note that y in conjunction with $\varkappa, \varphi, u$, is always used as $ю$ in the texts of the Uzhhorod Half-Uncial: возвожю УП, 120 а, доушю УП, 12 а, ицюцихъ УП, 182 а, кожю УП, 20 а, межю собою УП, 68 б, надежю УП, 19 б, насы нюсА УП, 204 б, наоучю вась УП, 67 б, нашю УП, 10 б, пишю УП, 11 а, препоғашютьсл УП, 11 б, притчю УП, 14 б, пришедшю УП, 156 б, солжють, в соушю УП, 10 б, оуврачюета УП, 166 б, честнбишю УП, 7 б, всњми чювьствы УП, 9 б, в чюдесъхъ УП, 3 а, шюма волны УП, 11 a etc, but in conjunction with $a$ the forms are non-palatal: дйа УП, $67 \mathrm{a}$, единочадаго, чадомъ УП, 64 а, начало УП, 16 б, оусльшиать УП, 67 а, часы УП, 181 a and the like. Similar spelling features we found in the Teachings of Ephraim the Syryn: въльможа СС, 303 зв., печали $\mathrm{CC}$, 62 зв., одежю СС, 23, почюд вмыся СС, 148, прикълючються СС, 16, чюжъмь $\mathrm{EC}, 86$ зв. and others. It is noteworthy that in religious monuments of the previous century, this trend is also present.

In the texts of the Mukachevo Psalter such a pattern is not observed, although there are confusions: ищазаеть МП, 67, 118, льщаах х МП, 5, подвижасл МП, 96, 113, подрбжаніе МП, 43, поръпщх (m) МП, 58, съгорАщх МП, 7, шоумомь МП, 9 - велер бчю Ащеи МП, 34, въжАжда МП, 41, въшоумъил МП, 45, ищезоша МП, 36, 63, 101, постидБиАса МП, 52, раздрбииша МП, 10, см Хтииш Ас А МП, 17, чюдеса МП, 25, чАлюсти МП, 31 etc.

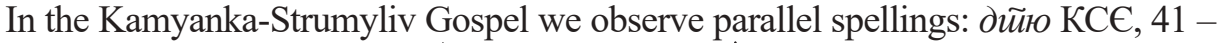

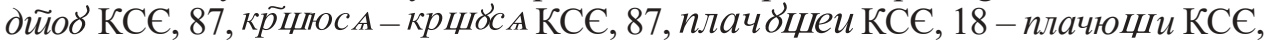
200 зв., притча КСЄ, 89 зв. - притчю КСЄ, 34 зв., 35, 38 зв., чठдеса КСЄ, 48 - чюдесе КСЕ, 203 зв. So along with depatalized forms: безначалнаго КСС, 8, бол Ашаға КСЕ, 27, начат КСС, 146, прелшаетес А КСЕ, 51, одбогашас АСС, 75 зв., аше хошов КСС, 110 зв. etc., - the softness of the consonants is reflected: бывию КСС, 60 зв., врачю КСЄ, 111, глшю КСЄ, 41 зв., ФтрочА КСЄ, 168 зв., праведничю КСЄ, 29, обмлъчА КСЄ, 50 зВ., чюждаго КСЄ, 181, чАда КСЄ, 28 and others.

The confusion of hushings is quite consistently evidenced in the lists of Ismaragd: вашю Ізм. № 488, 43, жАтели Ізм. № 488, 227, моужю Ізм. № 488, 8 зв., плачю Ізм. № 488, 53 зв., причАстникы Ізм. № 488, 226 зв., сходАшю Ізм. № 488, 13, твор АШю Ізм. № 488, 19 зв., тъжю Ізм. № 488, 55 зв. - венчаеть Ізм. № 488, 22, възбоужаите Ізм. № 488, 40, жадаи Ізм. № 488, 4 зв., не $\omega($ m) чаи- 
мо Ізм. № 488, 3 зв., $\omega(m)$ ча Ізм. № 488, 47 зв., почали Ізм. № 488, 8 зв., чаровь Ізм. № 488, 55, не шепчbl Ізм. № 489, 48 зв. еtс.

Cases of dissimilation in pronoun forms are not recorded in the liturgical books of the $14^{\text {th }}$ century, which may indicate the stability of traditional spelling: $\mathrm{kmo} \mathrm{ПА,}$ 116 а, кто ЛЄ, 2, кто КП, 5 зв., кто БА, 3 зв., 14, кто ПЄ, 2, кто ЄВ, 2 а, 8 а, нікто ЛС, 14 зв., никто ЛП, 9 зв., никто же БА, 33 зв., никто же ПС, 3, никто же ЄВ, 4 а, ньктоже Лавр Є, 80 зв., нкто ПЄ, 100, что ПА, 110 б, чьто ЛЄ, 14, что ЛП, 13 зв., что КП, 9 зв., что ПЄ, 2, что ЄВ, 118 б, ничто же ЛС, 6 зв., ничто же КП, 103, ничто же БА, 3 зв., почто БА, 1 and many similar. However, at the end of the $15^{\text {th }}$ century, new forms of such words appeared: $x m o$ Ізм. № 488, 3 зв., 7 зв., нихто Ізм. № 489, 26, 77 зв., ито Ізм. № 488, 6, штобы Ізм. №488, 7 зв., шито(ж) Ізм. № 488, 10, штоль Ізм. № 488, 3 зв., ништо Ізм. № 488, 5, нъито Ізм. № 488, 9 зв., пошто Ізм. № 488, 14 зв. and others.

Occasionally we record examples of simplification of sounds in groups of consonants: празника КП, 101 зв - праздьноуюшаго КП, 57 зв., лестномоу БА, 36, местьника ЛП, 7 зв., мАсопоустнана ПЄ, 121, непричастьна ЛП, 8 зв., праздьника ПЄ, 22, праздноугте БА, 1 зв., распоустьныға ПЄ, 74, сердьиемь КП, 10, сыропоустнаға ПЄ, 124, срдимь Лавр Є, 93 зв., срдчнаго ПЄ, 68, въ слнии ЛП, 23 зв., оустьны ЛП, 14 еtс.; сличю УП, 118 б - слнщю УП, 123 б, сриче трезвашеса УП, 87 а - срдйю УП, 191 б, and also: празникы МП, 73, празноу Ащаго МП, 41, прӥчасникъ УП, 2 а, оупразнитес А МП, 45, празнуйте, but бога $($ т)ство, че(с)тный Ап, 70, 72 and others.

Reflection of the Proto-Slavic sound combination $* d j$ attracts attention by spelling the vernacular in accordance with the Old Bulgarian ж⿱: гражане граждғане Лавр $6,104$.

In the texts of the Pandects of Antiochus, the Lutsk and the Kyiv Psalters, the Bybelskyi Apostle, the Lavryshiv Gospel, the Putna Gospel, the Gospels and the Gospel of Verkovich, the sound combinations * $d j$, *zdj were continued by the following continuants:

*dj > ж: in nouns: гражане ПЄ, 117, гражаны ПА, 42 б, исхоженье КП, 180, надежа Лавр С, 14 зв., надеже ЛП, 9 зв., надежю БА, 4, въ наслаженьи ЛП, 8 зв., ноужю же имнше ПЄ, 195, одежа ПА, 207 б, въ одежахъ ПЄ, 116, Фдежею Лавр Є, 78 зв., Фружьє ЛП, 18, Фсужънью Лавр Є, 7 зв., оутверженью ЛП, 20, оутвержение КП, 97 зв. and others;

in adjectives: слажьша ЛП, 27, хоужьшею БА, 6 зв. etc;

in verb forms: вижь (imperative mood) ЛП, 11, въгажаюџе ПА, 109 б, въсажь же (imperative mood) ПЄ, 103, дажь (imperative mood) ЛП, 10, заблоужьшаға Лавр Є, 44, жажюше КП, 152 зв., обижю ПА, 83 а, пошажю БА, 26, прихожю Лавр Є, 27, роженое ПС, 6, дрЂво саженою ЛП, 1 зв., свобожаґмъ ПА, 25 а, стыжюся ЛП, 31, соужю Лавр Є, 12, троужающагося Полікарп $\mathrm{\text {, }}$ 112 and many others; 
in adverbs: nръже ЛП, 18 зв., пьръже ПА, 61 а, пръже БА, 33 etc.

*dj, *zdj > жd: in nouns: дождь КП, 96 зв., дождь ПЄ, 56, дъжда ПА, 123 б, дрож(д)ьға 102 зв., жажду ПЄ, 191, рождьє Лавр Є, 39 зв. and others;

in adjectives: чюждихь $\mathrm{CB}, 31$ б еtс.;

in verb forms: въждельныи ЛП, 24, жыжд хита ПЄ, 122, Фсбж(д)енъ КП, 7 зв., повъждъ СВ, 88 б, пригвожденъи ЛП, 19 зв. раждь же мА ЛП, 17 зВ., раждежес А КП, 150, рождени СВ, 183 а, страждеши ПЄ, 96, троужда $L \mathrm{~K} m \mathrm{cA} \Pi €, 60$ and the like;

in adverbs: $n р \not ж д е ~ \Pi €, 192$ and others;

*dj > ждьж (ждеж): раждьжено ЛП, 14 зв., раждежена ЛП, 22, раждежено КП, 14 зв. and the like;

*zdj > жч: дожчь Лавр С, 51 зв, 52, 82 and others, Фдъжчи Лавр Є, 104 etc.

The dominant continuum of the Proto-Slavic sound combination *dj in the religious monuments of the $15^{\text {th }}$ century was the Old Bulgarian combination $ж \partial$ : дождь, заблоуждениға, злостраждеть, не Фдождити по земли, Фсбждаеши, постраждите Ап, 72-73; in the Mukachevo Psalter: въжАжда МП, 41, Фдъждить МП, 10, да не постижджсл МП, 70, съзиж(д)еть МП, 126, оутвръждени МП, 150, хождаа (x) МП, 141, but: инорожь МП, 28; in the Kamyanka-Strumyliv Gospel: бездождїе КСЄ, 208 зв., виждъ КСС, 91 зв., дождъ КСЄ, 23, междъ събою КСЄ, 43 зв., ноъжда КСЄ, 146 зв., прежде КСЄ, 195 зв., чюждаго КСС, 181, but: межи цргковїю КСС, 53. Linguistic fluctuations in the Uzhhorod Half-Uncial, associated with the continuum of *dj, are represented in the spelling of жд, ж, жж оутверждены УП, 87 a - оутвержение УП, 208 a, рожешюю УП, 90 б influence of live speech appear ж, зжд: преже Ізм. № 489, 19, гражано(м) Ізм. № 488, 32 зв., межи Ізм. № 488, 18 зв., одежа Ізм. № 488, 42 зв., побъжсаемъ Ізм. № 489, 15 зв., повъжь Ізм. № 488, 20 зв., прироженї А Ізм. № 488, 4 зв., разждаетс А (!) Ізм. № 488, 41 зв., разсоужан Ізм. № 488, 58, оутверженіе Ізм. № 488, 15 зв., ғажь (imperative mood) Ізм. № 488, 16 зв. etc.

The combination жu is used in the Teachings of Ephraim the Syryn: дъжчевнаго, СС, 14, изможчалая СС, 95, изможчаньжмь СС, 123, ражченеши СС, 179 зв., ражчеть, ражчвнью СС, 125-125 зв., ражчьжеть СС, 61 зв.

Reflexes of sound combinations $* \boldsymbol{t} \boldsymbol{j}$, $\boldsymbol{*} \boldsymbol{k} \boldsymbol{t}$ are represented by the traditional spelling of ш $(\varkappa m, m)$ : in nouns: ношь ЛП 38 зв., нощи СС, 154 зв., до ноши КП, 17, ношью ПЄ, 6, Фгньноу ЛП, 26, пещь МП, 20, полоуноши ПЄ, 86, полоуношница УП, 10 б,

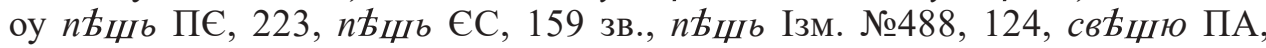
61 a and the like; in adjectives: ношнаго УП, 86 б, ношьнана КП, 126 зв., пвцьнаго ПА, 26 б, пъщьноге $\mathrm{CC,} 103$ зв. еtс.; in verb forms: посъщю 124 зв., свъцаша ЛП, 37 зв. and others; in adverbs: вноши КП, 120 and many others, but: печерьскаго УП, 156 б. 
Conclusions. Thus, as a result of the analysis of the texts of religious monuments of the $14^{\text {th }}-15^{\text {th }}$ centuries, clear signs of the interaction of the Old Bulgarian graphic and orthographic system and the Ukrainian folk speech were recorded. Manifestations of the phonetic and graphic South Slavic-Ukrainian variability are associated with the following linguistic phenomena: continuity of the former ${ }^{*} e,{ }^{*} a$ and ${ }^{*} Q$; change of the initial *je into $o$; transition of $e$ into $o$ after hushings and $u$; reduction of $u>b$ before iotated vowels; confusion of unstressed $u$ and $e$; development of sound

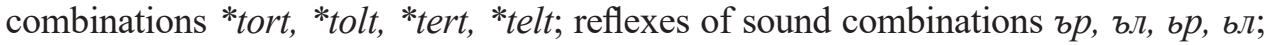
hardening of $p$ '; hardness/softness of hushing consonants; dissimilation and simplification of consonants; change of sound combinations ${ }^{*} d j$, ${ }^{*} z d j$ and ${ }^{*} t j$, ${ }^{*} k t$.

In the phonetic system of the studied monuments, the interaction of the traditional writing of that time and the local vernacular is traced, in particular, the phonetic features of the North Ukrainian and the South-West Ukrainian dialects are revealed. Due to the fact that the sacred books were transcribed by local residents (Ukrainians), the newly created manuscripts contained many different spellings from the original, which reflected the peculiarities of oral regional speech of scribes. Ancient dialectal features of the living language penetrated into the orthoepy of the sacred language, which led to a gradual departure from the Old Slavic written usus and the emergence of variants of liturgical orthoepy. Dialectal phonetic features are reflected in the liturgical manuscripts created in the Ukrainian lands, graphically not to the same extent. In certain cases, it is reasonable to assume that some phonetic features were quite strongly developed in the scribe's language, but he could not reproduce them due to the orthographic traditions of religious book-writing of that time, which were based on the Old Bulgarian language basis. In general, we can conclude that the process of approaching the church language to the living vernacular acquired an organic understanding and a certain dynamic.

\section{Prospects of the study}

The study of the language of religious monuments taking into account the results of other research in the field of philology, paleography, theology has undeniable prospects for linguistic interpretation of church books with the definition of local language traditions of the time, their localization as elements of the Slavic written culture, resolving debatable issues regarding the formation, chronology and systematization of the church-written corpus.

\section{Conditional symbols}

Aп - Karpinskij, M. (1888). Yuzhno-russkij Apostol XV veka. [The South Russian Apostle of the $15^{\text {th }}$ century]. Russkij filologicheskij vestnik, 19, 68-73. Varshava.

БА - Kopko, P. (1912). Apostolus Bybliensis saec. XIV. Grammatisch-kritisch Analysiert. Kaiserliche Akademie der Wissenschaften in Wien. Philosophischhistorische Klasse. Denkschriften, 55 (1), 1 - 103. Wien. 
EB - Kulbakin, S.M. (1901). Evangelie Verkovicha XIII - XIV v. Otchet o zanyatiyah v knigohranilishah Moskvy i Peterburga. [The Gospel of Verkovich of the $13^{\text {th }}-14^{\text {th }}$ centuries. Report on the lessons in the book depositories of Moscow and St. Petersburg]. Sbornik Otdeleniya russkogo yazyka i slovesnosti Imperatorskoj Akademii Nauk, 59 (3), 2 - 20.

EC - Sobolevskij, A.I. (1884) Poucheniya Efrema Sirina 1492 goda. [The teachings of Ephraim the Syryn of 1492]. Trudy po istorii russkogo yazyka, 1. Ocherki po istorii russkogo yazyka, 50 - 58. Kiev.

Ізм. № 488, Ізм. № 489 - Trebin, O. (1910). Materialy do istorii ukrainskoi movy z rukopysiv XV viku kyivskykh bibliotek. [Materials on the history of the Ukrainian language from the $15^{\text {th }}$ century manuscripts of Kyiv libraries]. Zapysky Ukrainskoho naukovoho tovarystva $v$ Kyievi, 7, 1-16.

KC - Sopko, O.I. (2015). Korolevske Yevanheliie $1401 r$. [The Korolevo Gospel of 1401]. Uzhhorod: Grazhda.

КП - Kievskaya Psaltir 1397 goda iz Gosudarstvennoj Publichnoj biblioteki imeni M. E. Saltykova-Shedrina v Leningrade. (1978). [The Kyiv Psalter of 1397 from the State Public Library named after M.E. Saltykov-Shchedrin in Leningrad]. Moskva.

KC€ - Kryzhanovskij, G. (1886). Kamenec-Stromilovskoe tetraevangelie 1411 goda i volynskoe narechie v XIV - XV vv. [The Kamenets-Stromilov tetra-Gospel of 1411 and the Volyn dialect in the $14^{\text {th }}-15^{\text {th }}$ centuries]. Volynskie Eparhialnye vedomosti, 17, $502-509 ; 18,531-540$.

Лавр C - Svencickij, I.S. (1913). Lavrashevskoe Evangelie nachala XIV veka (Paleograficheski-grammaticheskoe opisanie). [The Lauryshev Gospel of the beginning of the $14^{\text {th }}$ century (Paleographic and grammatical description)]. Izvestiya otdeleniya russkogo yazyka i slovesnosti Imperatorskoj Akademii Nauk, XVIII (1), $206-229$. Sankt-Peterburg.

ЛС - Lutske Yevanheliie XIV stolittia. Faksymilne vydannia. (2011). [The Lutsk Gospel of the $14^{\text {th }}$ century. Facsimile edition]. Kyiv.

ЛП - Lutskyi Psaltyr 1384 roku. Faksymilne vydannia. (2013). [The Lutsk Psalter of 1384. Facsimile edition]. Kyiv.

MП - Sokolov, I.I. (1883). Mukachevskaya psaltyr XV veka. [The Mukachevo Psalter of the $15^{\text {th }}$ century]. Sbornik statej po slavyanovedeniyu, sostavlennyj $i$ izdannyj uchenikami V. I. Lamanskogo po sluchayu 25-letiya ego uchenoj $i$ professorskoj deyatelnosti, 450 - 468. Sankt-Peterburg.

ПА - Pandekty Antiokha 1307 r. Natsionalnyi muzei u Lvovi imeni Andreia Sheptytskoho. Rukopys 48/257. [The Pandects of Antioch of 1307. Andrei Sheptytsky National Museum in Lviv. Manuscript 48/257].

$\Pi €$ - Kałużniacki, Aem. (1888). Evangeliarium Putnanum. Monumenta linguae palaeoslovenicae, $1,1-270$. Wien-Teschen.

Полікарп $\mathrm{C}$ - Kalajdovich, K.F. (1824). Ioann, ekzarh Bolgarskij: Issledovanie, obyasnyayushee istoriyu slavyanskogo yazyka i literatury IX i X stoletij. [John, Ex- 
arch of Bulgaria: Study explaining the history of the Slavic language and literature in the $9^{\text {th }}$ and $10^{\text {th }}$ centuries]. Moskva.

УП - Kolessa, О. (1925). „Uzhhorodskyi Poluustav” u pergaminovii rukopysi XIV v. [The Uzhhorodskyi Poluustav in a parchment manuscript of the $14^{\text {th }}$ century]. Zapysky NTSh, $141-143,1-59$. Lviv.

Четья - Nimchuk, V. (2015). Ukrainska Chetia 1489 roku. [The Ukrainian hagiography of 1489]. Zhytomyr.

\section{REFERENCES}

Jagic, V. (1894). „Ismaragd” ein altrussisches Literaturdenkmal. [Review of "To the literary history of the Old Russian collections" of V.A. Yakovlev]. Archiv fur slavische philologie, 16, 240 - 242. Berlin.

Kopko, P. (1912). Apostolus Bybliensis saec. XIV. Grammatischkritisch Analysiert. Kaiserliche Akademie der Wissenschaften in Wien. Philosophisch-historische Klasse. Denkschriften, 55 (1), 1-103. Wien.

McRobert, C.M. (2010). The textual peculiarities of the Luck Psalter of 1384 (Acquisti e Doni MS 360, Biblioteca Medicea Laurenziana, Florence). Ricerche slavistiche, 8 (54), New Series, 101 - 125.

Nandriş, Gr. (1924). Aspectele verbale in Evangheliarul slav de la Putna (sec. XIII - XIV). Codrul Cosminului. Analele Stiintifice ale Universitatii "Stefan cel Mare" din Suceava, 1, 9-18.

Popesku, P. (1962). Manuscrisele slavone din mănăstirea Putna. Biserica Ortodoxă Romină, 1 - 2, 105 - 145.

Smorąg-Różycka, M. (1999). Ewangeliarz Ławryszewski. Kraków.

Stradomski, J. (2014). Rękopisy i teksty. Studia nad cerkiewnosłowiańską kulturą literacką Wielkiego Księstwa Litewskiego i Korony Polskiej do końca XVI wieku. Krakowsko-wileńskie studia slawistyczne, 10. Kraków.

Verdiani, C. (1954). Il Salterio Laurenziano-Voliniense: Codice paleoslavo del 1384. Ricerche slavistiche, III, $1-29$.

Anichjenka, W.V. (1966). Knizhna-carkownaslavjanskija tradycyi v ukrainskaj i belaruskaj perekladnoj pismennasci XVI - XVII st. [The Book-Church Slavonic traditions in the Ukrainian and Belarusian translated writing of the $16^{\text {th }}-17^{\text {th }}$ centuries]. Slavia, $1,68-70$.

Bulakhovskyi, L.A. (1977). Vybrani pratsi: $v 5$ t. T. 2. [Selected works: in 5 volumes. V. 2]. Kyiv, Ukraine.

Nimchuk, V. (1997). Kyivskyi Psaltyr 1397 roku - pamiatka pivnichnoho dialektu ukrainskoi movy. [The Kyiv Psalter of 1397 - the monument of the northern dialect of the Ukrainian language]. Ukrainskyi dialektolohichnyi zbirnyk, 3, 218 - 231. Kyiv, Ukraine: Naukova dumka.

Shevelov, Yu. (2002). Istorychna fonolohiia ukrainskoi movy. [Historical phonology of the Ukrainian language]. Kharkiv, Ukraine: Akta. 
Skab, M.V. (2014). Tserkovnoslovianska mova ukrainskoi redaktsii: istoriia vynyknennia ta funktsionuvannia, hrafika, orfohrafia, fonetyka, leksyka. [The Church Slavonic language of the Ukrainian edition: history of origin and functioning, graphics, spelling, phonetics, vocabulary]. Chernivtsi, Ukraine.

Stamenova, A. (2017). Istoriya leksicheskih drevnebolgarizmov $v$ ukrainskom literaturnom yazyke. [History of lexical Old Bolgarisms in the Ukrainian literary language]. Sofia, Bulgaria: Paradox.

Temchin, S.Yu. (2009). Funkcionirovanie ruskoj movy i ierarhiya cerkovnyh tekstov. [The functioning of the Russian language and the hierarchy of church texts]. Studia Russica, XXIII, 226 - 234. Budapest, Hungary.

Tsaralunga, I. (2017). Pivdennoslovianski movni elementy v ukrainskomoldavskykh hramotakh XIV - XV st. [The South Slavic language elements in the Ukrainian-Moldavian letters of the $14^{\text {th }}-15^{\text {th }}$ centuries]. In: Multikulturalizm i mnogoezichie. Sbornik s dokladi ot Trinadesetite mezhdunarodni slavistichni cheteniya. Sofia, $21-23$ april 2016 g. T. 1. Lingvistika. Veliko Trnovo, Bulgaria.

Uspenskij, B.A. (1994). Kratkij ocherk istorii russkogo literaturnogo yazyka $(X I-X I X v v$.). [A brief outline of the history of the Russian literary language $\left(11^{\text {th }}-19^{\text {th }}\right.$ centuries $\left.)\right]$. Moskva, Russia: Gnozis.

Zhukovskaya, L. P. (1959). O perevodah evangeliya na slavyanskij yazyk i o "drevnerusskoj redakcii" slavyanskogo evangeliya. [About translations of the Gospel into the Slavic language and about" the Old Russian edition" of the Slavic Gospel]. Slavyanskoe yazykoznanie. Sb. statej, 86 - 97. Moskva, Russia.

Zhukovskaya, L.P. (1976). Tekstologiya i yazyk drevnejshih slavyanskih pamyatnikov. [Textology and language of the oldest Slavic monuments]. Moskva, Russia.

$\triangle$ Prof. Inna Tsaralunga
Scopus Author ID: 57193385975
Web of Science Researcher ID: AAE-4150-2020
ORCID iD: 0000-0002-7937-8529
Department of Ukrainian Philology
Khmelnytsky National University
Khmelnytsky, Ukraine
E-mail: tsaralungainna@ukr.net

